\title{
EKSISTENSI SASTRA LISAN MAHALABIU BAGI MASYARAKAT BANJAR KALIMANTAN SELATAN
}

\author{
Rustam Effendi \\ Fakultas Kegutusn Ilmu Pendidikan Unlam Banjarmasin \\ e-mail: rustam.efendi@yahoo.com
}

\begin{abstract}
Abstrak
Penelitian ini bertujuan mendeskripsikan bentuk, latar penuturan, dan fungsi mahalabiu bagi masyarakat Banjar. Metode yang digunakan dalam penelitian ini adalah metode deskriptif kualitatif. Data diperoleh melalui observasi dan wawancara mendalam dengan informan. Hasil penelitian sebagai berikut. Pertama, terdapat dua bentuk mahalabiu, yaitu (a) cerita lucu dan (b) kalimat atau frase pendek. Kedua, penuturan mahalabiu mempertimbangkan dua aspek, yaitu (a) latar tempat, waktu, situasi, dan (b) penutur dan kawan tutur. Ketiga, mahalabiu efektif sebagai alat pemertahanan bahasa Banjar dan sebagai media kritik sosial. Bahasa Banjar yang digunakan dalam mahalabiu sedikit sekali dipengaruhi bahasa daerah lain atau bahasa Indonesia, baik dilihat dari pemakaian kosa kata maupun kaidah kalimat.
\end{abstract}

Kata kunci: bentuk, fungsi, pemertahanan bahasa Banjar, kritik sosial

\section{THE EXISTENCE OF THE SPOKEN LITERATURE MAHALABIU FOR THE BANJAR COMMUNITY, SOUTH KALIMANTAN}

\begin{abstract}
This study aims to describe the forms, utterance settings, and functions of mahalabiu for the Banjar community. It employed the qualitative descriptive method. The data were collected through observations and in-depth interviews with informants. The findings are as follows. First, there are two forms of mahalabiu, i.e. (a) humorous stories and (b) short phrases or sentences. Second, the utterance of mahalabiu takes account of two aspects, i.e. (a) spatial, temporal, and situational settings, and (b) the speaker and listener. Third, mahalabiu is effective as a means of maintaining the Banjar language and as a medium of social criticism. The Banjar language in mahalabiu is not much influenced by other local languages or the Indonesian language in terms of the vocabulary and syntax.
\end{abstract}

Keywords: forms, functions, Banjar language maintenance, social criticism

\section{PENDAHULUAN}

Salah satu jenis tradisi lisan Banjar yang sangat digemari masyarakat Banjar sekarang ini adalah mahalabiu. Mahalabiu berasal dari kata halabiu (nama sebuah kota) yang mendapat prefiks -ma sehingga menjadi mahalabiu. Dalam bahasa Banjar, salah satu fungsi prefiks -ma adalah membentuk kata kerja yang bermakna 'mempunyai sifat seperti yang ada pada kata dasar'. Jadi, mahalabiu berarti orang yang mempunyai sifat seperti orang Halabiu. Beberapa informan mengatakan bahwa kata mahalabiu mungkin pula berasal dari kata mahala 'tanggung' dan biu (bentuk singkat Halabiu). Jadi, mahalabiu bermakna ungkapan kata/frase/kalimat/ wacana yang tidak selesai atau tanggung dan mengandung makna konotatif sehingga orang yang mendengar ungkapan mahalabiu harus berpikir sepenuh daya baru dapat menebak makna sesungguh- 
nya.

Orang Halabiu dikenal sebagai subetnik Banjar yang gemar membuat ceritacerita lucu. Seorang informan, mengemukakan bahawa mahalabiu diperkirakan berasal dari orang-orang Halabiu, sedangkan orang lain selain dari orang Halabiu hanyalah 'sebagai penyambung lidah atau peniru' kebiasaan orang Halabiu. Orang Halabiu, di mana pun mereka berada (di pasar, kedai, rapat, rumah tangga) sering membumbui pembicaraannya dengan canda atau joke yang menggelikan.

Cerita-cerita yang mengandung tekateki yang dibuat oleh orang-orang Halabiu dengan cepat menyebar dan diceritakan lagi oleh orang-orang lain yang mendengarnya. Seperti kebanyakan cerita lisan yang lain (legenda, dongeng, dan lainlain), mahalabiu itu direkabentuk lagi oleh seseorang yang lain sehingga menambah kelucuan mahalabiu. Seseorang dapat juga membuat mahalabiu yang baru yang kurang lebih sama (beranalogi) dengan mahalabiu yang pernah didengarnya. Walaupun mahalabiu itu pada awal mulanya adalah milik orang Halabiu, namun kenyataan sekarang, siapapun yang bertutur kata mahalabiu, orang Halabiu atau bukan orang Halabiu, maka orang itu dikatakan mahalabiu.

Mahalabiu merupakan karya sastra tradisional Banjar yang diturun-temurunkan secara lisan. Mahalabiu merupakan varian dari cucupatian (teka-teki Banjar) dan sekaligus menggantikan kedudukan cuсupatian yang telah punah. Sebagai sastra lisan, maka mahalabiu mempunyai beberapa ciri, yakni (i) diwariskan secara lisan, (ii) banyak versi, (iii) tidak diketahui siapa yang mengarang, (iv) mempunyai fungsi, (v) bersifat pralogis, (vi) milik suatu kolektif masyarakat, dan (vii) bersifat polos dan lugu (Danandjaya, 1991).

Keberadaan sastra lisan di tengahtengah suatu etnik bukanlah tanpa maksud. Tidak ada karya seni mana pun yang berfungsi dalam situasi kosong (Teeuw, 1983). Duranti (2000) mengemukakan lima fungsi kebudayaan, yakni, (i) sebagai sistem pengetahuan, (ii) sebagai sistem komunikasi, (iii) sebagai sistem mediasi, (iv) sebagai sistem praktik, dan (v) sebagai sistem partisipasi.

Sudah pasti, sastra Banjar disampaikan dengan bahasa Banjar dan sastra Indonesia disampaikan dengan bahasa Indonesia. Bahasa Banjar adalah salah satu bahasa daerah di Indonesia. Sejak bahasa Indonesia diangkat sebagai bahasa nasional dan bahasa resmi, bahasa Indonesia melejit menjadi 'raksasa linguistik' yang mengatasi semua bahasa daerah di Indonesia. Alwi, dkk. (2000) menyatakan bahwa bahasa Indonesia merupakan bahasa yang terpenting di antara beratusratus bahasa daerah yang jumlah penuturnya ada yang hanya beberapa ratus orang (misalnya di Irian Jaya) dan ada yang mencapai tujuh puluh juta orang seperti bahasa Jawa.

Politik Bahasa Nasional telah menentukan bahwa bahasa Indonesia mempunyai dua macam kedudukan, yakni sebagai bahasa nasional dan bahasa resmi. Sebagai bahasa nasional, bahasa Indonesia berfungsi sebagai lambang kebanggaan nasional, lambang identitas nasional, alat pemersatu berbagai masyarakat yang berbeda-beda latar belakang sosial budaya dan bahasanya, dan alat perhubungan antarbudaya dan antardaerah. Sebagai bahasa negara, bahasa Indonesia berfungsi sebagai bahasa resmi negara, bahasa pengantar resmi di lembaga-lembaga pendidikan, bahasa resmi di dalam perhubungan tingkat nasional untuk kepentingan perencanaan dan pelaksanaan pembangunan dan pemerintahan, dan bahasa resmi di dalam pembangunan kebudayaan dan pemanfaatan ilmu pengetahuan dan teknologi modern (Ramlan, 2008). Dengan fungsi itu maka prestise bahasa Indonesia dengan mudah melampaui prestise bahasa-bahasa daerah. Dengan kata lain, di negara-negara multilingual, seperti halnya Indonesia, bahasa resmi adalah bahasa yang wajib dikuasai oleh semua 
warganya sehingga menjadi bahasa yang tangguh dari kelompok mayoritas (majority) dan di lain pihak, bahasa daerah yang hanya digunakan oleh masyarakat daerahnya menjadi bahasa lemah dari kelompok minoritas (minority).

Isu bahasa dan budaya minoritas dan mayoritas telah lama menjadi isu global. Sehubungan dengan hal tersebut, Gibbons dan Ramirez (2004) mengemukakan:

A major challenge for linguistic minorities, whether indigenous, refugee or migrant, is the maintenance of their language and culture. In almost all societies around the world, the nationalist myths that societies are (or can be) homogenous culturally, linguistically and ethnically, have led to the overt or covert suppression and linguistic difference, and sometimes the 'cleansing' of ethnic difference (including genocide).

Dalam konteks ini dapat dilihat bahwa untuk melestarikan bahasa dan budaya minoritas bukanlah hal yang mudah. Pada tingkat global, bahasa Inggris dan budaya Barat dianggap sebagai ' pemangsa' (Hornberger, 1997) yang akan melemahkan bahasa dan budaya lain di dunia. Gibbons \& Ramirez (2004) mengemukakan lagi:

The asociation of national identity with majority language monolingualism is an attitude common to many societies around the world. Dorian (1981) mengemukakan pula, "Maintaining a language other than the majority one requires a clear and strong alternative belief structure, in which bilingualism and national identity are not mutually exclusive. those in the second generation of migrants who lack such a belief structure will often fail to develop their own language beyond semi-speaker level, and may not transmit the minority language to their children.
Sikap bahasa masyarakat yang demikian tentu sangat merugikan bahasa dan budaya minoritas. Sikap itu tumbuh dan mudah ditumbuhkan di kalangan masyarakat yang tidak terlalu faham terhadap fungsi dan teori bahasa. Mereka beranggapan bahwa bahasa atau variasi bahasa tertentu lebih baik dari yang lain. Sebuah bahasa atau variasi bahasa lebih indah, lebih mampu mengemukakan ekspresi daripada bahasa atau variasi yang lain.

Sebagai bahasa daerah, keberadaan bahasa Banjar pada saat sekarang juga sangat mengkhawatirkan. Banyak kosa kata bahasa Banjar yang hilang dan digantikan oleh kosa kata bahasa Indonesia. Dikhawatirkan, pada suatu saat, bahasa Banjar hanyalah sebuah nama sebuah bahasa daerah di Indonesia sedangkan wujudnya (kosa kata, struktur) adalah sama dengan bahasa Indonesia (Sumarsono, 1990). Untuk itulah, sejak sekarang, upaya pemertahanan bahasa Banjar harus ditingkatkan. Salah satu peluang untuk memertahankan bahasa Banjar adalah penggunaan bahasa Banjar melalui sastra lisan mahalabiu.

\section{METODE}

Penelitian ini menggunakan metode deskriptif dan pendekatan kualitatif. Data diperoleh dari hasil pengamatan dan wawancara terhadap sepuluh orang informan yang terdiri dari dua orang budayawan, dua orang penggemar mahalabiu, dan enam orang mahasiswa. Sumber data yang paling penting dalam penelitian kualitatif adalah tuturan dan tindakan yang menyertai tuturan. Tuturan tidak berdiri sendiri. Tuturan sebagai representasi dan atau tanggapan terhadap alam sekitar selalu beriringan dengan tindakan sebagai konsekuensi tuturan. Data yang diperoleh dari pengamatan dan wawancara dideskripsikan secara cermat dan detail sehingga dapat menggambarkan bentuk mahalabiu, lingkungan penuturan mahalabiu, dan fungsi mahalabiu. 


\section{HASIL DAN PEMBAHASAN \\ Bentuk Mahalabiu}

Istilah bentuk mempunyai makna yang sama dengan jenis dan macam (Brogan, 1994). Sudjiman (1990) mengemukakan bahwa bentuk adalah cara dan gaya dalam penyusunan dan penyusunan bahagia-bahagian karangan atau pola struktur karya sastra. Ada dua macam bentuk mahalabiu, yakni (i) berupa cerita yang lucu atau porno, dan (ii) berupa sebuah kalimat dan atau frasa yang berisi teka-teki.

Dalam konteks ini, istilah cerita dalam mahalabiu adalah cerita yang sangat pendek (bukan cerpen). Cerita mahalabiu tidak lebih dari lima belas kalimat. Tekateki dalam mahalabiu juga berbeda dengan teka-teki Banjar. Teka-teki Banjar yang disebut cucupatian dan mahalabiu memiliki ciri yang berbeda, seperti tampak pada tabel 1.

Tabel 1 Perbedaan Ciri Cucupatian dan Mahalabiu

\begin{tabular}{ll}
\hline \multicolumn{1}{c}{ Cucupatian (Teka-Teki) } & \multicolumn{1}{c}{ Mahalabiu } \\
\hline tradisional & kontemporer \\
masyarakat pedesaan & masyarakat pedesaan dan kota \\
telah punah & masih hidup \\
bentuk kalimat pendek, pantun, & kalimat pendek dan cerita yang \\
syair, karmina & pendek \\
menggunakan gaya bahasa dan & menggunakan kata, frasa, wacana \\
atau majas & yang bermakna ganda/taksa \\
fungsi utama mengasah & fungsi utama untuk kritik sosial, \\
kemampuan penalaran & pemertahanan bahasa, dan pelipur \\
& lara \\
\hline
\end{tabular}

Mahalabiu yang berbentuk cerita dikelompokkan menjadi dua macam, yakni mahalabiu berupa cerita yang mengandung teka-teki, teka-teki itu dapat tersurat dan tersirat dan mahalabiu yang berbentuk cerita murni (tanpa teka-teki). Cerita mahalabiu yang berisi teka-teki tersurat biasanya menggunakan kata tangguh Ikam, napa nah 'Kamu terka apa ya'. Contoh mahalabiu berupa cerita yang berisi tekateki tersurat.

Amun cangang ka hadapan maharap pambariannya. Amun cangang ka atas mangharap ganalnya pambariannya. Amun cangang ka bawah maliat tampat bardirinya. Tangguh ikam, napa nah (Kalau memandang ke depan mengharapakan pemberiannya. Kalau memandang ke atas mengharapkan besarnya pemberiannya. Kalau memandang ke bawah melihat tempat berdirinya. Kamu terka, apa ya?).

Jawaban mahalabiu ini adalah urang baunjun 'orang mengail'. Orang mengail apabila memandang ke hadapan, yakni memandang ke arah ujung kailnya, dia mengharapkan pemberian dari Yang Maha Pemberi, berupa ikan yang besar. Kemudian, apabila mata pancingnya sudah ditelan ikan maka pancing itu disentakkannya ke atas. Pada saat itu, ia melihat ke atas memandang ikan yang menggelepar tergantung-gantung di ujung kailnya dan melihat seberapa 'besarnya' pemberian-Nya. Akhirnya, pada saat memandang ke bawah, dia memandang tempat berpijak saat memancing ikan itu. Contoh lain mahalabiu ini sebagai berikut. 
Julak tulak sidik bajukung batalu badangsanak. Jukung dikayuh sidin mulai di Muhara Kuin. Imbah kada lawas bakayuh, kada bakatahuan datang umbak sing ganalan malimpuar maranjah jukung sidin tu. Jukung tabalik, karam.

Sabarataan tanyalam ka dalam banyu. Ayupang tangguh. Barapa ikung sidin nang batalu tu nang basah rambutnya (Paman pergi tiga saudara bersampan. Sampan dikayuh beliau mulai Muara Kuin. Setelah tidak lama mengayuh sampan, tiba-tiba datang ombak sangat besar menabrak sampan. Sampan terbalik, karam. Semua tenggelam ke dalam air. Cobalah terka. Berapa orang di antara mereka yang bertiga itu yang basah rambutnya).

Jawaban untuk mahalabiu ini tidak menentu. Yang basah rambutnya bisa dua orang sedangkan satu orang rambutnya tidak basah karena kepalanya botak (tidak berambut), atau tidak ada yang basah rambutnya karena semuanya berkepala botak.

Mahalabiu berupa cerita dengan tekateki tersirat adalah mahalabiu berisi tekateki namun teka-teki itu hanya sekedar pendamping cerita. Dengan kata lain, teka-teki pada mahalabiu ini tidak diutamakan, yang diutamakan adalah ceritanya bukan teka-tekinya. Contoh mahalabiu ini sebagai berikut.

"Bubuhan ikam sabarataan ni tahualah kanapa bibinan wayahini barabut handak balaki guru," ujar Palui manakuni Garbus wan Tulamak. "Nang jalas, masa dapan tajamin lawan pahala jadi guru ganal jua," ujar Tulamak. "Bujur haja Makai, tapi jawabannya kada nitu, " ujar Palui. "napa sababnya Lui?" Ujar Tulamak.

"Ingat wayah sakulah dulu kam. Bubuhan guru katuju mambari ulangan. Ada nang saban hari ulangan tarus. Nah... amun urusan di ranjang, bibinian tu katuju banar mun baulang-ulang." Ujar Palui lihum. "Amun duktur palingan 3 kali sahari haja tapi amun guru bisa labih pada itu ulangannya." Ujar Palui

("Tahukah kamu, apa sebabnya wanita sekarang berebut ingin bersuami guru," Kata Palui bertanya kepada Garbus dan Tulamak. "Yang jelas, masa depan guru terjamin dan pahala menjadi guru itu besar juga." Ujar Tulamak menjawab. "Benar juga jawaban kamu itu, tetapi yang dimaksudkan bukan itu," kata Palui. "Kalau begitu, apa sebabnya Lui?" Kata Tulamak. "Ingat waktu kita bersekolah dahulu. Para guru suka sekali memberi ulangan. Hampir setiap hari ada ulangan. Nah, itulah sebabnya para wanita senang dengan guru. Mereka, kalau urusan di ranjang, sangat suka berulang-ulang." Banjarmasin Post, 4 Juni 2009).

Contoh mahalabiu yang murni berupa cerita (tanpa teka-teki).

Ada talu macam nang amun disuruh tuan guru kada kawa baindah. Nang partama amun disuruh jadi pangulu. Nang kadua amun disuruh naik haji. Nang katiga amun disuruh kawin kawin lagi

(Ada tiga macam apabila disuruh seorang ustad tidak bisa menolak. Yang pertama apabila disuruh memjadi penghulu. Yang kedua apabila disuruh naik haji. Yang ketiga apabila disuruh kawin lagi).

Contoh mahalabiu yang berbentuk frasa dan atau kalimat sebagai berikut.

1) Hanyar samalam Ma Ilam mati sakalinya hari ini sudah ada untuk-untuk di warung Umanya Jariyah (Baru satu malam Ibu Ilam meninggal dunia, rupanya sudah ada untuk-untuk di warung Ibunya Jariyah).

2) Duit bagambar Soeharto di pagat kada payu (Uang bergambar Soeharto di pagat tidak laku).

3) Takuliling masigit kada taliat tikar sambahiyang (Sekeliling mesjid tidak terlihat tikar sembahyang). 
Pada contoh 1, terdapat kata untukuntuk yang bermakna ganda. Makna pertama adalah kepala yang bergoyanggoyang turun-naik (manggut-manggut) dan makna yang kedua adalah nama jenis kue (kue untuk-untuk). Mahalabiu mengecoh pendengarnya karena bagian kalimat sakalinya hari ini sudah ada untuk-untuk di warung dijadikan anak kalimat. Padahal, mahalabiu ini terdiri dari dua kalimat yang berbeda sehingga tidak bisa disambung dengan kata penghubung. Dengan kalimat ini, Ma Ilam yang sudah meninggal dunia menjadi makhluk yang menyeramkan karena masih terlihat untuk-untuk 'manggut-manggut' di warung Ibunya Jariyah.

Pada contoh 2, kata pagat bermakna ganda karena homofon. Dalam bahasa Banjar, kata pagat bisa berarti 'putus' dan berarti 'nama sebuah kota wisata'. Dengan demikian, makna mahalabiu ini adalah (a) uang yang bergambar Soeharto tidak laku karena uang itu robek menjadi dua bagian (pagat) atau (b) uang yang bergambar Soeharto tidak laku lagi di kota Pagat.

Pada contoh 3, mahalabiu dibuat dengan cara menghilangkan satu kata/frasa. Mahalabiu ini menjadi bermakna ganda karena tukang surung mahalabiu menggunakan bahasa Banjar lisan atau bahasa Banjar sehari-hari, bukan bahasa Banjar tulis. Dalam bahasa Banjar sehari-hari, kalimat diucapkan dengan singkat dengan cara menghilangkan satu kata atau frase agar komunikasi cepat berlangsung. Pada contoh ini, kata yang sengaja dihilangkan adalah sagan 'untuk'. Karena tidak ada kata sagan maka makna tikar sembahiyang menjadi ganda, yakni (a) tikar yang bersembahyang, dan (b) tikar untuk alas bersembahyang.

\section{Latar Penggunaan Mahalabiu}

Yang dimaksud latar atau lingkungan mahalabiu adalah latar belakang (background) penggunaan mahalabiu. Sudjiman (1990:48) mengatakan bahwa latar belakang adalah keadaan sosial, sejarah, dan sebagainya yang menjelaskan tejadinya lakuan (action). Latar belakang mencakupi juga istilah latar (setting). Latar adalah segala keterangan mengenai waktu, ruang, dan suasana terjadinya lakuan. Wellek (1968) menyebutkan bahwa latar merupakan lingkungan yang dapat berfungsi sebagai metonomia atau metafora untuk menggambarkan para tokoh. Ada titik berat kajian latar yang mungkin berbeda terhadap setiap genre-genre sastra. Baried (1985) mengemukan bahwa dalam mengkaji hikayat, misalnya, pengkajian latar dititikberatkan pada lingkungan atau suatu tempat terjadinya peristiwa.

Dalam penelitian ini, yang dimaksud latar atau lingkungan penggunaan mahalabiu adalah tentang latar penutur dan penuturan mahalabiu. Mahalabiu yang dituturkan secara lisan berkembang dalam satu lingkungan yang memungkinkan mahalabiu itu hidup dan berkembang serta berterima oleh masyarakat. Tidak sembarang mahalabiu dituturkan oleh seseorang di suatu tempat. Dengan kata lain, mahalabiu yang dituturkan oleh seseorang kepada orang lain harus mempertimbangkan faktor lingkungan sosial dan budaya. Seseorang yang mahir menggunakan mahalabiu biasanya sudah sangat cerdas menganalisis faktor sosial-budaya ini sehingga ia tahu pabila mahalabiu itu boleh digunakan.

Mahalabiu yang tidak tepat penggunaannya akan merugikan dua pihak, yakni si tukang surung mahalabiu dan pihak lain sebagai kawan bertutur. Merugikan karena pihak kedua atau kawan bertutur menganggap pihak pertama atau tukang surung mahalabiu itu sebagai orang yang tidak beradat. Seseorang yang mahir, baru mengajukan mahalabiu setelah melihat atau mempelajari situasi dan kondisi sosial budaya atau sikap sosial kawan bertutur. Boleh jadi, suatu mahalabiu boleh dituturkan oleh seseorang kepada seorang kawan bertutur, namun, pada waktu yang berbeda, mahalabiu itu tidak boleh lagi dituturkan walaupun ditujukan kepada 
kawan bertutur yang sama karena adanya perbedaan kondisi sosial.

Ada beberapa hal yang tampaknya perlu dipertimbangkan oleh seseorang bila mau menggunakan mahalabiu. Hal yang dipertimbangkan itu adalah: (i) latar (tempat, waktu, dan situasi), (ii) penutur dan kawan bertutur. Dua hal ini sangat berhubungan dengan faktor sosial-budaya masyarakat Banjar.

\section{Latar Penuturan Mahalabiu}

Latar adalah lingkungan penuturan mahalabiu. Latar meliputi tiga hal, yakni tempat, waktu, dan situasi. Ketiga hal itu secara bersama-sama membentuk latar mahalabiu sehingga mahalabiu boleh dimunculkan.

Latar tempat adalah tempat-tempat yang sering memunculkan interaksi mahalabiu. Tempat-tempat itu merupakan kawasan yang sangat digemari oleh masyarakat untuk berkumpul atau juga sebagai tempat suatu kegiatan lembaga kemasyarakatan. Tempat-tempat yang memungkinkan tumbuh suburnya mahalabiu adalah kedai minuman, sawah/ ladang, tempat pengajian (surau, mesjid, rumah penduduk), lingkungan sekolah/ kampus perguruan tinggi.

Kedai minuman atau makanan adalah tempat masyarakat desa berkumpul. Di tempat itu mereka membicarakan hal-hal kehidupan sehari-hari seperti pertanian, perkebunan, bahkan juga membicarakan hal-hal yang aktual dialami mereka, misalnya tentang kenaikan harga beras, harga pupuk, teroresme, dan lain-lain. Pada saat mereka berkumpul itu, sering seseorang menyindir atau mengeritik dengan cara mahalabiu. Mahalabiu juga muncul di sawah atau ladang pada saat baarian (gotong royong) bercocok tanam, mengetam padi, dan lain-lain.

Mahalabiu tidak hanya tumbuh dan berkembang di pedesaan tetapi juga di perkotaan dan dituturkan oleh seorang dosen di kampus atau seorang ustad di tempat-tempat pengajian, seperti di surau atau di mesjid. Dengan cara ini (mahalabiu) maka suasana menjadi hangat dan menyenangkan. Pada masyarakat petani desa, mahalabiu dihidupkan sewaktu mereka bekerja atau telah selesai bekerja. Pada saat bekerja, mahalabiu dituturkan mereka apabila matahari sudah mulai naik dan rasa lelah mulai terasa. Mereka mahalabiu untuk mengusir rasa kebosanan, berhibur diri, menambah gairah kerja, dan menumbuhkan rasa keakraban sesama kawan di tempat pekerjaan.

Selanjutnya, Mahalabiu dapat dilakukan pada situasi resmi (formal) dan tidak resmi (nonformal). Situasi resmi (formal) adalah situasi yang mengendaki keberaturan pelaksanaan suatu kegiatan. Dalam situasi resmi, seseorang harus tunduk pada ketentuan yang baku yang telah disepakati sejak lama. Saat batablik (berasal dari bahasa Arab tabligh), misalnya, yang berbicara hanyalah guru agama yang diundang sedangkan semua yang hadir tidak boleh ikut berbicara.

Mahalabiu yang dilakukan pada situasi resmi atau formal ialah mahalabiu yang dilakukan seperti pada saat (i) batablik, (ii) mambaca, (iii) pidatu pambakal, dan (iv) proses belajar-mengajar di sekolah. Batablik adalah ceramah agama yang khusus dilaksanakan untuk mencari keuangan untuk membangun langgar (surau), masigit (masjid), sakulahan (sekolah), atau lain-lain kepentingan sosial. Mambaca (membaca) adalah kegiatan mengajar ilmu agama di langgar (surau) dengan cara membaca kitab agama Islam. Mambaca dilakukan oleh guru di langgar atau di mesjid. Para peserta pengajian adalah masyarakat desa yang selalu setia datang ke pengajian itu. Mereka rela tidak bekerja demi menghadiri pengajian itu. Terkadang ada warga masyarakat yang sengaja tidak bekerja ke sawah karena pada hari pengajian itu dianggap sebagai hari yang penting. Guru sangat dihormati dan kata-kata atau nasihat-nasihatnya sangat kuat dipegang masyarakat. Seorang guru sering menggunakan mahalabiu untuk maksud membuat 
suasana menjadi santai dan untuk membantu pendengar meresapi pesan-pesan keagamaan yang disampaikannya.

Apabila penuturan mahalabiu dalam situasi resmi, arus komunikasi hanya boleh terjadi dalam satu arah maka dalam situasi tidak resmi arus komunikasi berlaku menjadi beberapa arah. Setiap orang boleh mengajukan mahalabiu dan atau menanggapinya sehingga keadaan menjadi ramai.

Mahalabiu dalam situasi tidak resmi biasanya dilakukan di suatu tempat seperti: (i) di dalam rumah tangga, (ii) di kedai, (iii) waktu baarian, (iv) di dalam mobil taksi/bus, (v) waktu bahandil, (vi) di toko, (vii) di kampus sebelum memulai kuliah,(viii) waktu baandak dan waktu pelaksanaan upacara tradisional. Bahandil adalah arisan tradisional yang diikuti oleh seluruh warga kampung yang sudah dewasa. Tidak ada ketentuan berapa besar uang yang disetorkan ke Panitia Bahandil. Setiap peserta, secara bergiliran, wajib menjadi tuan rumah dalam acara bahandil. Baandak adalah prakegiatan suatu kegiatan yang dianggap besar, seperti mengawinkan anak, acara maulud Nabi saw. Dalam prakegiatan (baandak), sanak keluarga yang jauh-jauh datang membantu menyiapkan sesuatu, seperti mencari umbut, membuat bumbu masak, mencari ikan, dan lain-lain. Mereka juga membawakan keperluan-keperluan lain, seperti beras, gula, dan lain-lain.

Bila mahalabiu dilakukan di rumah tangga maka pelakunya adalah antara suami-istri, ayah/ibu dan anak. Bila mahalabiu dilakukan oleh pelaku suami-istri, tanpa pendengar lain maka biasanya tema mahalabiu adalah tentang hal-hal yang lucu atau porno. Bila mahalabiu dilakukan antara orang tua (ayah/ibu) dengan anak-anak maka temanya berkisar pada permainan, pendidikan, atau hal-hal yang jenaka.

\section{Penutur dan Penuturan Mahalabiu}

Penutur mahalabiu adalah orang yang memulai mahalabiu atau tukang surung mahalabiu. Penuturan mahalabiu adalah segala kondisi yang melingkungi terjadinya mahalabiu, seperti tukang surung, penjawab, pendengar, dan latar mahalabiu.

Penutur mahalabiu diklasifikasikan menjadi sebelas macam, yakni: (i) suami kepada istri, (ii) ayah/ibu kepada anak, (iii) pedagang kepada pelanggan, (iv) tokoh masyarakat/pemimpin kepada anggota masyarakat, (v) anggota masyarakat desa kepada anggota masyarakat desa, (vi) anggota masyarakat kota kepada anggota masyarakat kota, (vii) guru kepada murid, (viii) anak-anak kepada anak-anak, (ix) guru pengajian kepada peserta pengajian, (x) dosen/guru kepada dosen/guru, (xi) dosen/guru kepada siswa/mahasiswa, (xii) mahasiswa kepada mahasiswa.

Sebagai contoh, di bawah ini dibicarakan mahalabiu yang dituturkan oleh seorang dosen kepada dosen lain. Apabila penutur adalah dosen dan pendengarnya atau penjawabnya adalah juga dosen maka mahalabiu itu dilakukan di luar ruang perkuliahan seperti di sudut-sudut atau pojok-pojok kampus. Mahalabiu dilakukan oleh dosen adalah untuk bergembira ria bersama kawan-kawan satu profesi untuk sementara ke luar dari dunia rutinitas yang setiap hari dikerjakan. Karena itu, tema mahalabiu biasanya berkisar pada hal-hal yang lucu atau jenaka. Sebagai contoh, seorang dosen menututurkan mahalabiu sebagai berikut.

Wayah ikam sumbahiyang mambaca tahayat akhir Asyhaduallaa ilaa hailallah, waasyhaduanna muhammadurrasulullah. Tunjuk kanan mancuking. Manurut ikam, napa nang ditunjuk tu

(Saat kamu sembahyang dan membaca tahayat akhir yang berbunyi Asyahadualla ilaha ilallah, waasyhaduanna Muhammadurrasulullah. Telunjuk lurus ke hadapan. Menurut Anda, apa yang ditunjuk). 
Mendengar tuturan mahalabiu ini, semua yang hadir menjadi riuh tertawa. Ada di antara mereka yang menjawab bahwa yang ditunjuk pada saat tahayat akhir adalah 'jiwa yang tenang,' ada lagi yang menjawab 'menunjuk kepada kebesaran Allah.' Jadi, pada saat itu terjalin rasa kekeluargaan antara dosen. Setelah tidak ada lagi yang mencoba menjawab mahalabiu ini, barulah jawaban yang benar diberitahukan oleh dosen tukang surung mahalabiu itu. Jawabannya adalah 'kuku' karena memang yang ada di tunjuk/telunjuk seseorang adalah kuku.

Selanjutnya, penuturan mahalabiu dapat diklasifikasikan menjadi tiga, yaitu (i) penuturan individual, (ii) penuturan berkelompok, dan (iii) penuturan surung kupak (bersahutan). Penuturan individual adalah mahalabiu yang dituturkan oleh seseorang karena kemauannya sendiri. Orang itu mahalabiu karena memang menyenangi atau sudah menjadi kebiasaan sehari-hari. Saat seseorang itu berada di tengah-tengah orang ramai, seperti di kedai, di dalam bus, di pahumaan (sawah) saat baarian, dan lain-lain, ia selalu memecah keheningan dengan tiba-tiba bersuara dengan mahalabiu. Dengan cara dia itu, tempat yang tadinya sunyi, serius, tiba-tiba menjadi ramai dan santai.

Penuturan berkelompok adalah mahalabiu yang dilakukan oleh beberapa orang seperti dalam kegiatan baarian mangatam (gotong royong mengetam padi). Pada kegiatan tersebut seseorang mahalabiu di tengah-tengah kelompok orang lainnya. Tanpa diatur terlebih dahulu, tiba-tiba kelompok itu terpecah menjadi dua, sebagian membantu tukang surung mahalabiu dan yang sebahagian lagi menjadi kelompok penjawab mahalabiu. Kelompok yang tergabung dalam tukang surung mahalabiu saling bantu-membantu atau saling memberi penguatan terhadap argumentasi tentang masalah yang terkandung dalam mahalabiu. Begitu juga kelompok yang berpihak kepada penjawab mahalabiu. Mereka semua kompak memberikan jawaban dan argumentasi untuk menguatkan jawaban yang diberikan.

Penuturan mahalabiu surung kupak adalah penuturan mahalabiu secara bersahutsahutan. Seseorang memulai mahalabiu dan dijawab oleh seseorang yang lainnya. Setelah menjawab, orang itu balik mahalabiu pula sebagai balasan.

\section{Fungsi Mahalabiu}

Ada dua fungsi utama mahalabiu, yakni sebagai alat pemertahan bahasa Banjar dan sebagai media kritik sosial. Kedua fungsi tersebut diuraikan pada sub-subbab berikut ini.

\section{Mahalabiu sebagai Alat Pemertahanan Bahasa Banjar}

Berkaitan dengan fungsi mahalibau sebagai alat pemertahanan bahasa Banjar, dikemukakan beberapa fungsi, yaitu (a) alat bantu pengingat kosa kata dan struktur bahasa Banjar, (b) sumber belajar bahasa Banjar, (c) ajang memeraktikkan bahasa Banjar dalam situasi alamiah (natural), dan (d) alat menumbuhkembangkan sikap positif terhadap bahasa Banjar. Fungsi-fungsi tersebut diuraikan sebagai berikut

Pertama, mahalabiu sebagai alat bantu pengingat kosa kata dan struktur bahasa Banjar. Mahalabiu adalah satu jenis sastra lisan Banjar yang paling sering dituturkan dibandingkan dengan jenis sastra yang lain seperti Lamut, Madihin, Pantun, Legende, Mite, dan lain-lain. Seringnya dituturkannya mahalabiu disebabkan oleh bentuknya yang singkat, berhubungan dengan fakta yang aktual, dan karena kandungan isinya yang bernada humor.

Sebagai jenis sastra yang berisi faktafakta aktual maka biasanya orang yang pertama menuturkan mahalabiu adalah orang-orang tua atau dewasa yang mempunyai banyak pengalaman hidup. Pada umumnya pula, bahasa mahalabiu yang dituturkan oleh para orang tua dan atau orang dewasa ini menggunakan bahasa Banjar yang asli (kosa kata, struktur, into- 
nasi) yang sangat sedikit pengaruh bahasa Indonesia.

Dalam mahalabiu banyak ditemukan kosa-kosa kata Bahasa Banjar yang tidak dipahami lagi oleh generasi muda sekarang. Bahkan, beberapa di antara kosa kata yang muncul dalam mahalabiu juga sudah tidak terekam dalam Kamus Bahasa Banjar (Hapip, 1997).

Enam orang mahasiswa yang diminta sebagai informan dalam penelitan ini mengaku bahwa bahasa Banjar dalam mahalabiu adalah bahasa Banjar yang agak asing karena banyak kosa kata yang tidak dikenal mereka. Mereka dapat menambah pengetahuan bahasa Banjar melalui mahalabiu.

Kedua, mahalabiu sebagai sumber belajar bahasa Banjar. Hingga saat ini, bahasa Banjar tidak menjadi mata pelajaran yang diwajibkan di sekolah-sekolah, baik di sekolah dasar (SD/MI), sekolah menengah pertama (SMP/MTs), dan di sekolah menengah atas (SMA/MA). Memang ada sebagian kecil sekolah yang memasukkan bahasa Banjar ke dalam kurikulum muatan lokal sekolah. Sebagai muatan lokal, pembinaan dan pengembangan bahasa Banjar tidak terlalu banyak berarti karena waktu yang dialokasikan sangat sedikit.

Semua informan sepakat mengatakan bahwa mahalabiu sangat membantu generasi muda dalam memahami dan menggunakan bahasa Banjar. Enam orang mahasiswa yang menjadi informan mengaku merasakan langsung manfaat mahalabiu untuk memahami bahasa Banjar. Beberapa kosa kata yang jarang muncul dalam pembicaraan sehari-hari ternyata muncul dalam tuturan mahalabiu.

Ketiga, mahalabiu sebagai ajang memeraktikkan bahasa Banjar dalam Situasi alamiah (natural). Dalam situasi nonformal, para mahasiswa memang menggunakan bahasa Banjar. Namun, bahasa Banjar yang mereka gunakan adalah bahasa Banjar yang telah tercampur dengan bahasa Indonesia. Lebih-lebih pada saat berkomunikasi dengan teman-temannya yang berasal dari etnik lain, bahasa Banjar yang mereka gunakan sudah tidak murni lagi, baik dilihat dari penggunaan kosa kata, struktur, dan intonasi.

Para informan mahasiswa mengatakan bahwa mahalabiu menuntut penggunaan bahasa Banjar yang sesungguhnya. Mahalabiu menjadi tidak menarik dan atau bahkan terkesan dibuat-buat apabila bahasa Banjar yang digunakan bercampur dengan bahasa Indonesia. Hal ini dapat dipahami karena budaya daerah, seperti humor akan tidak lucu lagi apabila diubah atau dicampurbaurkan dengan bahasa Indonesia atau bahasa lainnya.

Keempat, mahalabiu sebagai alat menumbuhkembangkan sikap positif terhadap bahasa Banjar. Mahalabiu tidak hanya digunakan oleh masyarakat desa tetapi juga digunakan oleh masyarakat perkotaan, bahkan, juga masyarakat kampus. Guru dan dosen mahalabiu pada saat waktu senggang dan bahkan pada saat proses belajar-mengajar. Para ustad mahalabiu pada saat menyampaikan ceramah agama di tempat-tempat umum, di surau atau di mesjid. Pengguna mahalabiu oleh para tokoh masyarakat (guru, dosen, ustad, lurah, camat, dan lain-lain) membuat kesan bahwa mahalabiu bukanlah suatu karya yang 'murahan'. Melihat kenyataan bahwa mahalabiu menjadi kegemaran para tokoh masyarakat maka mahasiswa dan atau generasi muda ikut pula meniru walaupun baru sebatas mengulang kembali mahalabiu yang pernah disampaikan oleh para tokoh masyarakat itu. Dengan fakta ini, mahalabiu dapat dikatakan mampu secara perlahan menumbuhkan sikap positif masyarakat Banjar terhadap bahasa Banjar.

\section{Mahalabiu sebagai Media Kritik Sosial}

Berkaitan dengan mahalabiu sebagai media kritik sosial, dikemukakan beberapa fungsi, yaitu (a) kritik terhadap diri sendiri, (b) kritik terhadap pemerintah, (c) kritik terhadap sesama etnik Banjar, (d) kritik terhadap etnik luar Banjar, (d) 
kritik terhadap ustad, (f) kritik terhadap cara berpikir masyarakat, (g) kritik terhadap perempuan, dan (h) kritik terhadap kebiasaan yang tidak baik. Fungsi-fungsi tersebut diuraikan sebagai berikut

Pertama, kritik terhadap diri sendiri. Contoh mahalabiu yang berisi kritik terhadap diri sendiri sebagai berikut.

Bini saikung balajar, bini dua wajar, bini tiga kurang ajar, bini ampat hanyar urang Banjar.

(Beristri satu baru belajar, beristri dua orang wajar saja, beristri tiga orang kurang ajar, beristri empat orang barulah benar-benar orang Banjar.)

Mahalabiu itu berisi kritik terhadap diri sendiri (otokritik) terhadap orang Banjar. Memang tidak banyak orang Banjar yang beristri lebih dari satu orang, namun kenyataan itu telah cukup menjadi bahan olok-olokan sekali gus sebagai media kritik terhadap orang Banjar yang beristri lebih dari satu orang. Apalagi, biasanya orang yang beristri lebih dari satu itu adalah orang yang secara ekonomi tidak mampu. Dia tidak dapat berlaku adil dan sering menelantarkan istri-istrinya. Ada lagi orang Banjar yang beristri lebih dari satu itu adalah orang-orang Banjar yang kaya mendadak karena memiliki lahan yang berisi tambang batu bara atau karena mendapat intan yang besar di pandulangan.

Mahalabiu ini terdiri daripada empat kalimat, (i) Bini saikung belajar, (ii) Bini dua wajar, (iii) Bini tiga kurang ajar, dan (iv) Bini ampat hanyar urang Banjar. Kalimatkalimat ini dijajarkan dengan gaya klimaks namun bernada sinisme. Lazimnya gaya klimaks, kalimat terakhir merupakan puncak pendeskripsian suatu hal atau keadaan yang ingin disampaikan. Begitu juga pada mahalabiu ini, kalimat keempat yang berbunyi "Bini ampat hanyar urang Banjar" seolah merupakan puncak pendeskripsian tentang prestasi dan prestise orang Banjar dalam hal berpoligami.
Contoh lain mahalabiu yang berisi kritik terhadap diri sendiri (kritik terhadap orang Banjar) adalah sebagai berikut.

Apa bidanya urang Banjar lawan urang Cina. Urang Banjar tu bapikir nang kaya apa mancari duit, urang Cina bapikir nang kaya apa manggunaakan duit. (Apa perbedaan antara orang Banjar dan orang Cina. Orang Banjar berpikir bagaimana mencari uang dan orang Cina berpikir bagaimana menggunakan uang).

Mahalabiu ini berisi kritik terhadap orang Banjar. Mahalabiu ini mau mengeritik pola hidup atau tata nilai ekonomi orang Banjar yang pikirannya sangat sempit, yaitu hari ke hari hanya giat mencari uang. Pekerjaan yang dilakukan pun tidak berubah dari hari ke hari, tahun ke tahun, seperti menyadap karet, berdagang keperluan sehari-hari (seperti gula, beras, ikan), bertani, berkebun, bertukang. Hasil dari usaha sehari hanya cukup untuk keperluan sehari pula. Yang lebih memprihatinkan, ada juga orang Banjar yang terpaksa harus berhutang karena uangnya dihabiskan untuk hal-hal yang bersifat konsumtif tidak untuk hal-hal yang produktif. Karena itu, sebagian orang Banjar dari hari ke hari selalu membanting tulang mencari uang. Setelah mendapatkan uang yang cukup, mereka membeli perabotan atau peralatan rumah tangga yang sebenarnya tidak terlalu penting.

Sebagian orang Banjar juga masih ada yang suka bermalas-malasan kalau telah mendapatkan uang yang banyak. Apabila melihat uang telah banyak terkumpul, sebagian orang Banjar menghentikan aktivitasnya, hidup bersuka cita menikmati sepuasnya hasil pekerjaannya. Bila uang itu menipis atau bahkan telah habis maka mereka mulai lagi bekerja mencari uang. Sikap yang semacam ini adalah warisan budaya tradisional yang pada masa dahulu boleh saja dilakukan namun pada masa sekarang budaya itu harus dibuang jauh. Pada masa lalu, ketika alam Banjar 
subur-makmur, sawah luas membentang, hutannya penuh dengan berbagai tumbuhan. Buah-buahan, seperti mangga, durian, langsat, rambutan, dan lain-lain tidak perlu di tanam karena alam Banjar yang subur telah memberinya. Pohon-pohon itu telah tumbuh dengan sendirinya di tepi-tepi rumah atau di semak-semak belukar. Apabila ingin kayu bakar, dia cukup ke belakang rumah membawa parang dan lanjung. Di belakang rumah, sudah berserakan ranting-ranting kayu yang kering berjatuhan. Begitu juga kalau mau ikan, mereka cukup membawa pancing dan duduk sebentar memancing ikan di depan rumahnya.

Pada masa itu, orang Banjar hidup terlena dimanjakan oleh alam. Sehubungan dengan itu pula, masyarakat Banjar tradisional membagi musim menjadi dua macam, yakni musim gawi dan musim diam. Musim gawi adalah musim melakukan aktivitas seperti bertani/bercocok tanam, biasanya dimulai pada awal musim hujan. Musim diam adalah musim setelah selesai memanen padi. Pada musim diam, orang Banjar (tradisional) hidup bermalas-malasan dan hura-hura dalam menikmati hasil panen yang diperoleh pada musim gawi yang lalu. Pada musim diam ini orang Banjar bakarasmin (mementaskan hiburan-hiburan seperti mamanda, balamut, bawayang, dan lain-lain). Kemudian, setelah musim hujan mulai datang, mulailah musim gawi, mereka bekerja lagi di sawah atau di ladang.

Sebaliknya, sebagian etnik Cina sangat pandai mencari uang. Mereka mendapatkan uang tidak melalui bekerja membanting tulang di sawah atau di ladang tetapi mereka mendapatkan dengan cara yang mudah yaitu melalui jasa bank. Dengan demikian, uang yang diperoleh itu harus segera digunakan. Mereka sangat pandai membaca peluang-peluang usaha yang menguntungkan sehingga dapat mengembalikan uang pinjaman itu sesuai waktunya. Jadi, inti dan hakikat mahalabiu ini adalah kritik terhadap diri orang Banjar itu sendiri. Etnik Banjar harus mengubah pandangannya tentang duit 'uang' yang sering digunakan untuk bermalas-malasan.

Kedua, mahalabiu berisi kritik terhadap pemerintah. Contoh mahalabiu yang berisi kritik terhadap pemerintah sebagai berikut.

Wayahini samuaan haraga barang naikan pada susu haja nang turun.

(Sekarang semua harga barang naik kecuali susu saja yang turun).

Mahalabiu ini berisi kritik terhadap pemerintah yang tidak mampu mengendalikan harga-harga barang. Mahalabiu ini biasanya diucapkan pada bulan puasa (Ramadan). Pada masa itu, terlebih-lebih menjelang hari raya, harga barang selalu naik. Masyarakat yang kesal terhadap keadaan ini lalu membuat kalimat-kalimat mahalabiu seperti di atas. Dalam mahalabiu ini dikatakan bahwa semua harga barang naik kecuali 'susu' saja yang turun. Orang yang mendengar mahalabiu bertanyatanya, mengapa harga susu dikatakan turun padahal kenyataannya harga susu di pasar juga naik. Ternyata, yang dimaksud dengan susu dalam mahalabiu ini bukan susu sapi tetapi susu perempuan yang semakin hari semakin turun seiring usianya yang juga bertambah tua.

Contoh lain mahalabiu yang berisi kritik terhadap pemerintah adalah sebagai berikut.

Jalan kita ni kada suah baik, batambah rusak haja hari ka hari tahun ka tahun. Inya bupatinya kada mau diaspal.

(Jalan kita ini tidak pernah baik, dari hari ke hari, tahun ke tahun hanya bertambah rusak saja, disebabkan Bupatinya tidak mahu diaspal.)

Mahalabiu ini berisi kritik yang sangat pedas terhadap Bupati sebagai seorang kepala pemerintahan di daerah. Orang mengucapkan mahalabiu ini karena kesal melihat jalan di kampungnya yang selalu rusak, tidak pernah baik. Kendaraan tidak 
dapat cepat bahkan ada yang rebah garagara terpeleset karena jalan yang licin dan berlubang-lubang.

Mahalabiu ini dibuat dengan cara memanipulasi struktur morfologi diaspal yang seharusnya berawalan me- ( kata kerja aktif) diubah menjadi berawalan di-(kata kerja pasif). Dalam bahasa Banjar yang baik, bagian kalimat ini seharusnya berbunyi, "Inya Bupatinya kada mau maasapal." Namun, untuk kepentingan mahalabiu, bentuk maaspal 'mengaspal' secara sengaja diubah menjadi diaspal 'diaspal'. Orang yang mendengar mahalabiu ini akan terbahak-bahak tertawa karena tidak aka ada Bupati yang mau dirinya diaspal (dibubuhi aspal).

Ketiga, mahalabiu berisi kritik terhadap sesama etnik Banjar. Berikut ini contoh mahalabiu berisi kritik terhadap sesame etnik Banjar.

Urang Halabiu tu nang kalah lawan urang Nagara haja. Urang Halabiu main bal lawan urang Nagara. Urang Nagara kalah anam bigi. Tapi biar kalah bubuhan Nagara tatap bulikan bamusik. Imbah ditakuni kanapa. Ujar urang Nagara, kami mangira kalah sapuluh. Mun kalah anam kada papa.

(Orang Halabiu kalah dengan orang Nagara saja. Ceritanya orang Halabiu bermain sepak bola dengan orang Nagara. Orang Nagara kalah enam biji. Walau demikian, orang Nagara pulang dengan membunyikan alatalat musik seperti senang sekali. Setelah ditanya mengapa kalah bermain bola justeru sangat senang. Mereka menjawab, kami mengira akan kalah sepuluh. Jadi, kalau kalah enam biji, itu tidak masalah.)

Mahalabiu ini mengkritik orang Halabiu (salah satu subetnik Banjar) yang selalu tidak mau kalah dalam membual. Kali ini, dia kalah dengan orang Nagara yaitu satu etnik yang menjadi tetangga dekatnya. Orang-orang Halabiu terheranheran mengapa orang Nagara yang kalah bermain bola dengan mereka justeru pulang dengan membunyikan alat-alat musik seperti orang kegirangan. Ternyata, mereka (orang Nagara) masih merasa menang karena hanya kalah enam biji, padahal dalam perkiraan, mereka kalah sepuluh biji.

Keempat, mahalabiu berisi kritik terhadap etnik luar Banjar. Berikut ini contoh mahalabiu tersebut.

Kayi lawan cucunya basampida ka pakan.

Nang kayi babuat diancak sampida. Di tangah jalan ada luang ganal. Kaya apa kayi manuyuruh cucunya supaya jangan maranjah luang nitu lawan bahasa Cina. Jawab: liung cu.

(Kakek dan cucunya bersepeda ke pasar. Kakek membonceng di belakang sepeda. Di tengah jalan ada lubang yang besar. Bagaimana kakek menyuruh cucunya agar tidak tertabrak lubang itu dengan bahasa Cina. Jawab: liung $\mathrm{cu}$.

Mahalabiu ini berisi kritik terhadap bahasa Cina yang dianggap oleh orang Banjar sangat lucu dan sukar dimengerti. Jawaban mahalabiu 'liung $c u^{\prime}$ adalah bahasa Banjar yang bermakna 'hindari cu.' Kata-kata bahasa Banjar ini dianggap seperti bahasa Cina dan diucapkan dengan meniru logat cina menjadi 'li ung cu.' Orang yang mendengar jawaban mahalabiu ini akan tertawa terbahak-bahak karena merasakan kelucuannya dan teringat kepada etnik Cina yang bahasanya dianggap lucu.

Kelima, kritik terhadap ustad sebagaimana tampak pada kutipan mahalabiu berikut ini.

Ada talu macam parmintaan nang kada kawa ditulak tuan guru. Partama disuruh naik haji, kadua disuruh jadi pangulu, katiga disuruh kawin pulang.

(Ada tiga macam permintaan yang tidak mungkin ditolak oleh seorang tuan guru 'ustad'. Pertama disuruh menunaikan ibadah haji, kedua di- 
minta menjadi penghulu, dan ketiga disuruh kawin lagi).

Mahalabiu ini berisi kritik terhadap tuan guru atau guru-guru agama yang mengajarkan agama di masjid atau surau. Tuan guru bukan pegawai pemerintah tetapi hidup dari hasil sumbangan peserta pengajian. Kadang-kadang seorang tuan guru mendatangi puluhan mesjid/surau setiap minggu. Jarak antara rumah dan masjid/surau yang dia datangi cukup jauh, sehingga tidak jarang dia terpaksa bermalam di salah satu rumah warga peserta pengajian. Dengan alasan jarak yang jauh dan juga mungkin karena sering bermalam di suatu kampung maka ada tuan guru yang kawin lagi. Walau hanya sedikit tuan guru yang suka kawin dan kawin sehingga istrinya sampai empat orang, namun, fakta itu sudah cukup bagi masyarakat Banjar untuk mengeritiknya. Dengan mahalabiu ini dapat diketahui bahwa masyarakat Banjar, terlebih para wanita, belum dapat menerima konsep poligami.

Keenam, mahalabiu berisi kritik terhadap cara berpikir masyarakat. Contoh mahalabiu berisi kritik terhadap cara berpikir masyarakat tampak pada kutipan berikut ini.

Urang mambaca yasin kada bulih di kubur

(Orang membaca Yasin tidak boleh dikubur)

Mahalabiu mengandung makna yang taksa, yakni, pertama 'melarang membaca Yasin (salah satu surat di dalam Alquran) di kubur,' dan kedua, 'orang membaca Yasin jangan dimasukkan ke liang kubur.' Mahalabiu ini mengkritik dua kubu cara berpikir masyarakat dalam hal membaca Yasin ketika berziarah kubur. Ada masyarakat yang merasa puas apabila dapat membaca Yasin di kubur sanak saudaranya, terlebih menjelang hari raya Idul Fitri, namun, di lain pihak ada yang tidak membenarkan membaca Yasin (termasuk surat Alquran lainnya) di atas kubur. Menurut mereka, membaca Alquran cukup di rumah atau di tempattempat lain yang terjamin kesucian atau kebersihannya.

Contoh lain mahalabiu yang berisi kritik terhadap cara berpikir masyarakat adalah seperti pada mahalabiu di bawah ini.

\section{Urang mati kada kawa dibangakan. \\ (Orang mati tidak boleh diazankan.)}

Mahalabiu ini berisi kritik terhadap dua kubu cara berpikir masyarakat tentang azan pada saat memasukkan jenazah ke liang lahat. Satu kubu berpendapat bahwa sangat baik dikumandangkan azan pada saat mau memasukkan jenazah ke liang kubur dan satu pihak lagi melarang karena azan itu hanya dikumandangkan apabila mau melaksanakan sembahyang lima waktu.

Ketuju, mahalabiu berisi kritik terhadap perempuan sebagaimana tampak pada kutipan sebagai berikut.

Nangapa sasamaannya bibinian lawan warik. Sama-sama bapasang rantai di pinggang.

(Apa persamaannya perempuan dengan kera. Sama-sama memasang rantai di pinggang.)

Mahalabiu ini berisi kritik terhadap perempuan yang berlebihan dalam berdandan. Perempuan yang seperti itu dikritik dengan cara membandingkannya dengan seekor kera peliharaan. Seekor kera peliharaan biasanya di pinggangnya terpasang rantai pengikat agar kera itu tidak lari atau berjalan jauh. Dengan kritik ini diharapkan seorang perempuan tidak berlebihan dalam menggunakan ikat pinggang atau dandanan lainnya.

Mahalabiu yang berisi kritik terhadap perempuan dapat dilihat lagi pada contoh seperti berikut.

Nangapa bidanya tukang cat lawan bibinian. Tukang cat mancat rumah bibinian 
mancat bibir.

(Apa perbedaan tukang cat dengan perempuan. Tukang cat bekerja mengecat rumah sedangkan perempuan mengecat bibir.)

Mahalabiu ini mengkritik perempuan yang terlalu mencolok dalam menggunakan lipstik. Bibirnya merah menyala atau memakai lipstik warna lainnya yang sangat mencolok. Dengan mahalabiu ini diharapkan perempuan dapat berdandan sesuai nilai-nilai budaya masyarakat, yakni tidak berlebih-lebihan.

Kedelapan, mahalabiu berisi kritik terhadap kebiasaan yang tidak baik. Kutipan berikut ini contoh mahalabiu tersebut.

Nangapa kapanjangan PARGUM. Kapanjangannya Parsatuan Guring Malandau. (Apa makna singkatan PARGUM. Maknanya adalah Persatuan Tidur Malandau 'bangun tidur selalu kesiangan.)

Mahalabiu ini mengeritik kebiasaan seseorang (suami, isteri, anak, atau orang lain) yang bangun tidur selalu kesiangan. Dalam tradisi budaya Banjar ada anggapan bahwa orang yang selalu bangun siang kada parazakian (tidak akan mendapat rezeki yang banyak) karena rezekinya telah lebih dahulu dipatuk hayam (dimakan oleh ayam). Sehubungan dengan ini, orang yang selalu terlambat bangun pada pagi hari dikritik dengan mahalabiu ini.

Contoh lain mahalabiu yang mengeritik kebiasaan yang tidak baik adalah sebagai berikut.

Nangapa kapanjangan PPL. Kapanjangannya Parsatuan Pandir Layau.

(Apa makna singkatan PPL. Maknanya Persatuan Pandir 'berbicara' Layau 'berbicara ke sana ke mari, tidak terarah.')

Mahalabiu ini mengeritik orang-orang yang pembicaraannya tidak terarah, ke sana ke mari, bahkan berisi hal-hal yang belum jelas kebenarannya atau mengarah kepada fitnah. Pembicaraan yang mengungkap hal-hal yang belum jelas kebenarannya, fitnah, tidak terarah kepada hal-hal yang penting atau yang diperlukan, dikritik dengan mahalabiu ini. Dalam budaya Banjar pembicaraan yang demikian harus dihindari karena "kada jadi baras banih" (tidak akan menjadi beras atau padi atau tidak berguna, bahkan menimbulkan sengketa).

\section{SIMPULAN}

Semua uraian yang dikemukakan telah memperlihatkan bahwa mahalabiu dapat berfungsi sebagai alat memertahankan bahasa Banjar dan menjadi media masyarakat Banjar dalam mengeritik berbagai kepincangan sosial yang ada dalam masyarakat. Kritik itu sangat penting disimak oleh setiap orang, khususnya orang Banjar sendiri, termasuk pemimpin pemerintahan dan tokoh-tokoh masyarakatnya.

Mahalabiu merupakan karya sastra lisan masyarakat Banjar yang paling sering muncul apabila dibandingkan dengan karya-karya sastra lisan Banjar lainnya. Mahalabiu dituturkan oleh berbagai lapisan masyarakat seperti petani, pedagang, lurah, camat, dosen, dan lain-lain. Mahalabiu pun bergema di berbagai latar seperti sawah, warung teh, balai desa, surau, mesjid, dan lain-lain. Melihat kenyataan seperti di atas, maka selayaknya pemerintah daerah dan tokoh-tokoh masyarakat Banjar memikirkan suatu strategi pemberdayaan mahalabiu sebagai sarana penularan nilai-nilai yang positif.

\section{UCAPAN TERIMA KASIH}

Ucapan terima kasih disampaikan kepada informan yang telah membantu pelaksanaan pengumpulan data, kepada mitra sejawat yang telah membantu kegiatan verifikasi dan triangulasi data serta kepada redaktur ahli yang telah memberikan masukan terhadap artikel ini. Semoga tulisan ini bermanfaat dalam rangka mempelajari kekayaan sastra lisan, khususnya 
mahalabiu, sebagai alat memertahankan bahasa Banjar dan menjadi media dalam mengeritik berbagai kepincangan sosial yang ada dalam masyarakat Banjar.

\section{DAFTAR PUSTAKA}

Alwi, H., dkk. 2000. Tata Bahasa Baku Bahasa Indonesia. Jakarta: Balai Pustaka.

Baried, B. 1985. Memahami Hikayat dalam Sastra Indonesia. Jakarta: Pusat Pembinaan dan Pengembangan Bahasa, Departemen Pendidikan dan Kebudayaan.

Brogan, T. 1994. Handbook of Poetic Terms. New Jersey : Priceton University Press.

Danandjaya, J. 1991. Folklor Indonesia, Ilmu Gosip, Dongeng, dan Lain-Lain. Jakarta: Grafiti.

Dorian, N. 1981. Language Death: The Life Cycle of a Scottish Gaelic Dialect. Philadelphia PA: University of Philadelphia Press.

Duranti, A. 2000. Linguistic Anthropology. Cambridge : Cambridge Universiy.
Gibbons, J. \& Ramirez, E. 2004. Maintaining a Minority Language: A Case Study of Hispanic Teenagers . Clevedon,GBR: Multilingual Matters Limited.

Hapip, A. Dj. 1997. Kamus Bahasa BanjarIndonesia. Banjarmasin: PT Grafika Wangi Kalimantan.

Hornberger, N. 1997. Literacy, Language Maintenance and Linguistic Human Right: There Telling Cases. International Journal of the Sociology of Language, 87-103.

Ramlan, M. 2008. Kalimat, Konjungsi, dan Preposisi Bahasa Indonesia dalam Penulisan Karangan Ilmiah. Yogyakarta: Universitas Sanata Dharma.

Sudjiman, P. 1990. Kamus Istilah Sastra. Jakarta: Pustaka Jaya.

Sumarsono. 1993. Pemertahanan Bahasa Melayu Loloan di Bali. Jakarta: Pusat Pembinaan dan Pengembangan Bahasa.

Teeuw, A. 1983. Membaca dan Menilai Sastra. Jakarta: Gramedia.

Wellek, R. \& Warren, A. 1968. Theory of Literature. Harmondsworth: Penguin Books. 